\title{
On the wisdom of calculating annual material budgets in tidal wetlands
}

\author{
A. L. Murray, T. Spencer* \\ Department of Geography, University of Cambridge, Downing Place, Cambridge CB2 3EN, United Kingdom
}

\begin{abstract}
In the last decade, measurements of the tidal exchange of inorganic and organic materials, and their extrapolation for the calculation of annual budgets, have played an important role in assessing the ecological functioning and sedimentary status of coastal wetlands. Flux measurements, and their application to longer sequences of tidal flooding, for an enclosed back-barrier salt marsh in Norfolk, England, show how net import/export characteristics for a range of materials (total suspended sediment, inorganic suspended sediment, particulate organic carbon and dissolved organic carbon), and thus the interpretation of wetland function, are strongly dependent upon the method of budgetary calculation. Annual budgets should be evaluated in a broader context which explores differing combinations of flooding regime, sediment supply and surface accretion, and vegetation production and decay.
\end{abstract}

KEY WORDS: Salt marsh Tidal hydrodynamics Organıc carbon Suspended sediment - Northwest Europe

\section{INTRODUCTION}

Flux measurements have been carried out in many coastal wetlands (salt marsh and mangrove) systems in order to quantify the transports of both organic (e.g. Borey et al. 1983, Dame et al. 1986, Roman \& Daiber 1989, Williams et al. 1992, Taylor \& Allanson 1995) and inorganic materials (e.g. Woodroffe 1985, Wolaver et al. 1988). These studies attempt to extrapolate the exchanges from data collected over typically 10 to 50 tides per year up to annual figures (in excess of 700 tides) for the net import/export of a given class of material. These calculations are usually given as either mass exchange for the whole marsh per annum or as mass exchange per unit area of marsh per annum. It is important that these calculations produce reliable estimates of annual tidal material exchanges because such estimates have 3 important uses:

(1) To test Odum's $(1968,1980)$ 'outwelling hypothesis'; this suggests that salt marshes act as producers of nutrients for nearshore ecosystems. This hypothesis

\footnotetext{
- Addressee for correspondence.

E-mail: tsıll@hermes.cam.ac.uk
}

has formed the basis for many research programmes aimed at understanding the ecological function of marshes within the coastal zone (e.g. Dame et al. 1986, 1991). Much of this work attempts to quantify the net exchange of specific nutrients, such as organic forms of carbon, phosphorus and nitrogen, between salt marshes and estuarine/coastal water over a given time period, typically 1 yr. This approach is justified if it can be shown that the annual timescale is the most appropriate one for expressing net material exchange or if a time-series of annual measurements is made as means of establishing longer term trends.

(2) To standardise material exchange measurement as a means of comparison with other flux measurements, either at various scales within the same system (e.g. the Long-Term Ecological Research Project, at North Inlet, South Carolina, Childers et al. 1993) or in different marshes (Stevenson et al. 1988). Such comparisons obviously require that both the means of measuring tidal exchange and the procedure for estimating the annual budget are similar for each system or subsystem.

(3) To assess the sedimentary status of a coastal wetland through the comparison of net sediment flux mea- 
surements with a regional rate of relative sea-level change, itself typically expressed as an annual rate (e.g. Stevenson et al. 1988). Realistic assessments of coastal wetland sedimentary status are essential for the prediction of future changes in wetland area at lo$\mathrm{cal} / \mathrm{regional}$ scales. Assessments of marsh sedimentary status are critically dependent on the accuracy with which the annual sediment budget can be estimated.

A well-founded appraisal of the ability of current material budget estimates to fulfil these 3 objectives clearly necessitates an examination of the procedures employed in making these estimates and the viability of between-system comparisons. This paper examines these issues.

\section{METHODS}

Field site. Flux measurements were made at Salicornia Marsh, a small (0.88 ha) back-barrier marsh at Scolt Head Island, north Norfolk, with a simple third-order creek system (Strahler 1964) (Fig 1). Local tidal range is $6.4 \mathrm{~m}$ at Mean High Water Springs and the system is thus classified as meso-to-macrotidal. The system is dominated by externally derived inputs of mineral sediments (for models of marsh development see Allen 1990). Such marsh types are dominated by rapid accretion, and thus increase in surface elevation in relation to the tidal. frame, in the early stages of development. Salicornia Marsh. which has developed from an unvegetated mudflat in the last 50 to $60 \mathrm{yr}$, is currently accreting at $7 \mathrm{~mm} \mathrm{yr}^{-1}$ (Murray 1995). The marsh surface is characterised by a diverse plant community, including the species Suaeda maritima, Aster tripolium, Limonium vulgare and Salicornia spp. There are local patches of the cordgrass Spartina anglica, and Atriplex portulacoides fringes creek banks.

This site is ideally suited to direct flux measurements because it is almost completely enclosed by shingle ridges. These ridges prevent water which has entered the marsh via the creek system from leaving the backbarrier environment via adjacent creek drainage systems. As flood and ebb tide processes, and hence water levels, are largely synchronous in adjacent systems, marked gradients in hydraulic head do not develop across the shingle ridges. Seepage of water through these barriers is therefore not taken into account in the following budget calculations. The marsh surface is at 2.5 m OD (Ordnance Datum: 0 m OD approximates Mean Sea Level) and was inundated 390 times during the study period (Murray 1995). Tidal material exchanges were measured on 22 overmarsh tides between September 1992 and September 1993. The net material exchange for a single tide was assumed to be the difference between the mass of material imported to the marsh on the flood tide and the mass exported on the ebb.

Dataset. Tidal discharge was calculated for a section (Fig 1) near the mouth of the creek system draining the marsh surface using the velocity-area method, where discharge is the product of flow velocity and cross-sectional flow area. The cross-sectional area of the flow was separated into creek and overmarsh components where different flow velocities were observed. Creek velocity was measured using a 'Braystoke' impellor (Valeport, Dartmouth, UK), and overmarsh velocities were measured using an electromagnetic current meter (EMCM, Valeport, Druck Ltd, Leicester, UK). Flow depth (S) was measured using a calibrated pressure transducer (Druck PDCR). Areas of the creek $\left(A_{c}\right)$ and overmarsh $\left(A_{\text {ov }}\right)$ sections were related to flow depth using third order polynomial regressions

$$
\begin{gathered}
A_{c}=15.492-21.211 S+8.55 S^{2}-0.884 S^{3} \\
\left(R^{2}=0.998\right) \\
A_{n=}=190.843-249.657 S+91.495 S^{2}-8.955 S^{3} \\
\left(R^{2}=0.999\right)
\end{gathered}
$$

Measurements of flow velocity and depth were made at 5 min intervals throughout the tidal cycle. These cross-sectional and temporal sampling designs have been shown in earlier studies in N Norfolk (e.g. French \& Stoddart 1992) to best capture the variations in velocity experienced during tidal cycles within these marsh systems

The discharges associated with overmarsh and creek flows were calculated separately for each 5 min interval, and then summed for the flood and the ebb tides.

At 15 min intervals, an automated water sampler (ISCO, Green World Instruments, London, UK) was used to collect a $250 \mathrm{ml}$ water sample. Samples were filtered to determine the concentration of total suspended sediment (TSS). After removal of inorganic carbon (Williams et al. 1992), the filtration residue was oxidised at $800^{\circ} \mathrm{C}$, in the presence of a CuO catalyst, to determine the concentration of inorganic suspended sediment (ISS). The difference between TSS and ISS provided a measure of organic suspended sediment (OSS). The volume of $\mathrm{CO}_{2}$ gas evolved during oxidation was determined using an infrared spectrometer and gave a

Fig. 1. Salicornia Marsh and configuration of barrier and back-barner environments, Scolt Head Island, North Norfolk, England. (a) Western end of Scolt Head Island, showing saltmarsh, sand dune, and shingle ridge environments and Salicornia Marsh (b) Location of Scolt Head Island, southern North Sea. England. (c) Cross-section across study marsh, showing creek section and marginal shingle ridges [see (d)]. OD: Ordnance Datum. (d) Salicornia Marsh, showing marginal shingle ridges 

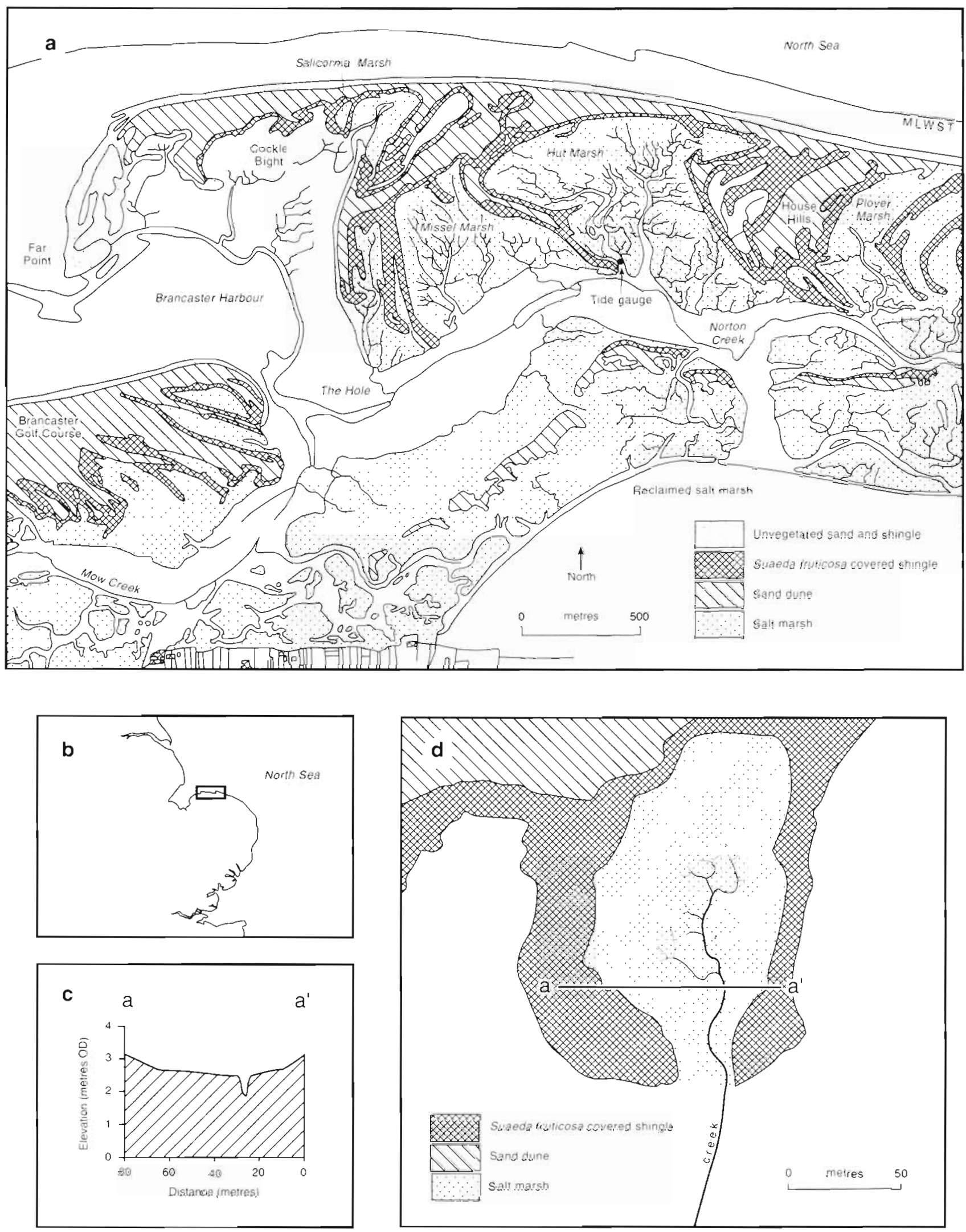
measure of particulate organic carbon (POC) concentration. DOC (dissolved organic carbon) concentration in the filtrate, following removal of inorganic carbon, was ascertained by persulphate-enhanced ultraviolet oxidation. This procedure converted organic compounds to $\mathrm{CO}_{2}$, which was measured in an infrared spectrometer (Statham \& Williams 1983).

The discharge and material concentration datasets collected for each tide were used to calculate the flood and ebb transports of TSS, ISS, OSS, POC and DOC. The net exchange of each class of material was assumed to be the difference between the flood and the ebb transport (Table 1). The flood, ebb and net material transports were used to generate annual budget estimates by a variety of methods. The next section describes these methods and compares the resulting annual budgets and associated errors.

Table 1 Flood and ebb transports and net exchanges of material fractions measured at the creek station in Salicornia Marsh, Scolt Head Island, North Norfolk, England. OD: Ordnance Datum: TSS, ISS and OSS: total, inorganic and organic suspended sediment, POC and DOC: particulate and dissolved organic carbon

\begin{tabular}{|c|c|c|c|c|c|c|c|}
\hline $\begin{array}{l}\text { Stage } \\
\text { (m OD) }\end{array}$ & $\begin{array}{c}\text { Residual water } \\
\text { transport as a } \\
\text { percentage of } 1 \text { lood } \\
\text { tidal prism }\end{array}$ & $\begin{array}{l}\text { Material } \\
\text { fraction }\end{array}$ & $\begin{array}{l}\text { Flood } \\
\text { transport } \\
(\mathrm{kg})\end{array}$ & $\begin{array}{l}\text { Ebb } \\
\text { transport } \\
(\mathrm{kg})\end{array}$ & $\begin{array}{l}\text { Net } \\
\text { exchange } \\
(\mathrm{kg})\end{array}$ & $\begin{array}{c}\text { Water } \\
\text { temperature } \\
\left({ }^{\circ} \mathrm{C}\right)\end{array}$ & Tide \\
\hline 3.75 & 16.81 & $\begin{array}{l}\text { TSS } \\
\text { ISS } \\
\text { OSS } \\
\text { POC } \\
\text { DOC }\end{array}$ & $\begin{array}{r}256.08 \\
236.50 \\
19.58 \\
9.51 \\
21.36\end{array}$ & $\begin{array}{r}199.27 \\
175.57 \\
23.70 \\
10.64 \\
22.28\end{array}$ & $\begin{array}{l}56.82 \\
60.93 \\
-4.12 \\
-1.13 \\
-0.92\end{array}$ & 14.6 & 28 Sep 1992 am \\
\hline 3.74 & 0.63 & $\begin{array}{l}\text { TSS } \\
\text { ISS } \\
\text { OSS } \\
\text { POC } \\
\text { DOC }\end{array}$ & $\begin{array}{r}228.85 \\
273.30 \\
15.55 \\
6.41 \\
23.07\end{array}$ & $\begin{array}{r}217.51 \\
206.75 \\
10.76 \\
9.38 \\
25.09\end{array}$ & $\begin{array}{r}71.34 \\
66.55 \\
4.79 \\
-2.97 \\
-2.02\end{array}$ & 13.9 & 27 Sep 1992 am \\
\hline 3.74 & 2.53 & $\begin{array}{l}\text { TSS } \\
\text { ISS } \\
\text { OSS } \\
\text { POC } \\
\text { DOC }\end{array}$ & $\begin{array}{r}644.46 \\
628.67 \\
15.79 \\
8.04 \\
14.41\end{array}$ & $\begin{array}{r}407.68 \\
391.42 \\
16.27 \\
7.64 \\
20.67\end{array}$ & $\begin{array}{r}236.77 \\
237.26 \\
-0.48 \\
1.40 \\
-6.26\end{array}$ & 5.6 & 09 Mar 1993 pm \\
\hline 3.65 & 36.71 & $\begin{array}{l}\text { TSS } \\
\text { DOC }\end{array}$ & $\begin{array}{r}659.43 \\
13.85\end{array}$ & $\begin{array}{r}264.43 \\
10.98\end{array}$ & $\begin{array}{r}395.00 \\
2.87\end{array}$ & 5.6 & 09 Feb 1993 pm \\
\hline 3.55 & 11.52 & $\begin{array}{l}\text { TSS } \\
\text { ISS } \\
\text { OSS } \\
\text { POC } \\
\text { DOC }\end{array}$ & $\begin{array}{r}583.09 \\
569.28 \\
13.82 \\
3.96 \\
15.29\end{array}$ & $\begin{array}{r}184.61 \\
172.95 \\
11.66 \\
4.13 \\
13.75\end{array}$ & $\begin{array}{r}398.48 \\
396.33 \\
2.16 \\
0.17 \\
1.54\end{array}$ & 5.2 & 10 Feb 1993 pm \\
\hline 3.53 & 23.85 & $\begin{array}{l}\text { TSS } \\
\text { ISS } \\
\text { OSS } \\
\text { POC } \\
\text { DOC }\end{array}$ & $\begin{array}{r}744.93 \\
723.28 \\
21.65 \\
6.66 \\
22.49\end{array}$ & $\begin{array}{r}321.39 \\
298.99 \\
22.40 \\
7.89 \\
15.05\end{array}$ & $\begin{array}{r}423.54 \\
424.29 \\
-0.75 \\
-1.23 \\
7.44\end{array}$ & 5.9 & 08 Feb 1993 pm \\
\hline 3.43 & 7.56 & $\begin{array}{l}\text { TSS } \\
\text { DOC }\end{array}$ & $\begin{array}{r}517.33 \\
20.74\end{array}$ & $\begin{array}{r}348.02 \\
14.74\end{array}$ & $\begin{array}{r}169.31 \\
6.00\end{array}$ & 5.8 & 07 Feb 1993 pm \\
\hline 3.42 & 10.18 & $\begin{array}{l}\text { TSS } \\
\text { ISS } \\
\text { OSS } \\
\text { POC } \\
\text { DOC }\end{array}$ & $\begin{array}{r}129.54 \\
119.70 \\
9.83 \\
3.33 \\
13.22\end{array}$ & $\begin{array}{r}96.55 \\
85.35 \\
11.20 \\
4.13 \\
14.49\end{array}$ & $\begin{array}{l}32.99 \\
34.35 \\
-1.37 \\
-0.80 \\
-1.27\end{array}$ & 15.9 & 21 Jul $1993 \mathrm{am}$ \\
\hline 3.35 & 2.42 & $\begin{array}{l}\text { TSS } \\
\text { ISS } \\
\text { OSS } \\
\text { POC }\end{array}$ & $\begin{array}{r}243.30 \\
229.25 \\
14.05 \\
6.06\end{array}$ & $\begin{array}{r}158.05 \\
145.36 \\
12.70 \\
4.99\end{array}$ & $\begin{array}{r}85.25 \\
83.89 \\
1.35 \\
1.07\end{array}$ & 13.6 & 15 Sep 1993 pm \\
\hline 3.34 & -2.53 & $\begin{array}{l}\text { TSS } \\
\text { ISS } \\
\text { OSS } \\
\text { POC } \\
\text { DOC }\end{array}$ & $\begin{array}{r}355.08 \\
336.66 \\
18.42 \\
8.27 \\
12.12\end{array}$ & $\begin{array}{r}190.21 \\
174.25 \\
16.00 \\
8.20 \\
12.39\end{array}$ & $\begin{array}{r}164.88 \\
162.41 \\
2.47 \\
0.06 \\
-0.27\end{array}$ & 5.6 & 12 Dec 1992 pm \\
\hline
\end{tabular}


Table 1 (continued)

\begin{tabular}{|c|c|c|c|c|c|c|c|}
\hline $\begin{array}{l}\text { Stage } \\
\text { (m OD) }\end{array}$ & $\begin{array}{l}\text { Residual water } \\
\text { transport as a } \\
\text { percentage of flood } \\
\text { tidal prism }\end{array}$ & $\begin{array}{l}\text { Material } \\
\text { fraction }\end{array}$ & $\begin{array}{l}\text { Flood } \\
\text { transport } \\
(\mathrm{kg})\end{array}$ & $\begin{array}{c}\text { Ebb } \\
\text { transport } \\
(\mathrm{kg})\end{array}$ & $\begin{array}{l}\text { Net } \\
\text { exchange } \\
(\mathrm{kg})\end{array}$ & $\begin{array}{c}\text { Water } \\
\text { temperature } \\
\left({ }^{\circ} \mathrm{C}\right)\end{array}$ & Tide \\
\hline 3.31 & 9.88 & $\begin{array}{l}\text { TSS } \\
\text { ISS } \\
\text { OSS } \\
\text { POC } \\
\text { DOC }\end{array}$ & $\begin{array}{r}209.17 \\
195.06 \\
14.11 \\
6.57 \\
17.17\end{array}$ & $\begin{array}{r}170.95 \\
160.09 \\
10.86 \\
5.41 \\
15.60\end{array}$ & $\begin{array}{r}38.23 \\
34.98 \\
3.25 \\
1.16 \\
1.57\end{array}$ & 14.1 & 30 Sep $1992 \mathrm{am}$ \\
\hline 3.3 & -1.66 & $\begin{array}{l}\text { TSS } \\
\text { ISS } \\
\text { OSS } \\
\text { POC } \\
\text { DOC }\end{array}$ & $\begin{array}{r}97.44 \\
89.30 \\
8.15 \\
2.93 \\
11.64\end{array}$ & $\begin{array}{r}89.74 \\
78.93 \\
10.81 \\
3.58 \\
15.96\end{array}$ & $\begin{array}{r}7.70 \\
10.36 \\
-2.66 \\
-0.65 \\
-4.32\end{array}$ & 16.1 & $20 \mathrm{Jul} 1993 \mathrm{am}$ \\
\hline 3.27 & -13.95 & $\begin{array}{l}\text { TSS } \\
\text { ISS } \\
\text { OSS } \\
\text { POC } \\
\text { DOC }\end{array}$ & $\begin{array}{r}396.34 \\
379.55 \\
16.80 \\
6.46 \\
15.45\end{array}$ & $\begin{array}{r}227.83 \\
209.85 \\
17.98 \\
6.99 \\
17.88\end{array}$ & $\begin{array}{r}168.51 \\
169.70 \\
-1.19 \\
-0.53 \\
-2.43\end{array}$ & 7.0 & 11 Dec $1992 \mathrm{pm}$ \\
\hline 3.17 & -4.38 & $\begin{array}{l}\text { TSS } \\
\text { ISS } \\
\text { OSS } \\
\text { POC } \\
\text { DOC }\end{array}$ & $\begin{array}{r}378.85 \\
371.71 \\
7.15 \\
2.54 \\
14.41\end{array}$ & $\begin{array}{r}356.88 \\
350.23 \\
6.65 \\
1.67 \\
16.16\end{array}$ & $\begin{array}{r}21.98 \\
21.48 \\
0.50 \\
0.87 \\
-1.75\end{array}$ & 13.4 & 05 May 1993 pm \\
\hline 3.1 & 4.34 & $\begin{array}{l}\text { TSS } \\
\text { ISS } \\
\text { OSS } \\
\text { POC }\end{array}$ & $\begin{array}{r}253.76 \\
240.94 \\
12.83 \\
5.05\end{array}$ & $\begin{array}{r}131.42 \\
111.25 \\
14.17 \\
6.81\end{array}$ & $\begin{array}{r}122.34 \\
123.69 \\
-1.34 \\
-1.76\end{array}$ & 13.6 & 14 Sep 1993 pm \\
\hline 3.06 & -9.64 & $\begin{array}{l}\text { TSS } \\
\text { ISS } \\
\text { OSS } \\
\text { POC } \\
\text { DOC }\end{array}$ & $\begin{array}{r}208.90 \\
200.29 \\
8.61 \\
2.61 \\
5.73\end{array}$ & $\begin{array}{r}150.48 \\
137.25 \\
13.23 \\
4.58 \\
8.60\end{array}$ & $\begin{array}{l}58.42 \\
63.04 \\
-4.62 \\
-1.97 \\
-2.87\end{array}$ & 5.8 & 07 Mar 1993 pm \\
\hline 3.05 & 2.68 & $\begin{array}{l}\text { TSS } \\
\text { ISS } \\
\text { OSS } \\
\text { POC } \\
\text { DOC }\end{array}$ & $\begin{array}{r}303.30 \\
287.08 \\
16.23 \\
8.36 \\
6.81\end{array}$ & $\begin{array}{r}170.03 \\
156.19 \\
13.84 \\
7.24 \\
7.32\end{array}$ & $\begin{array}{r}133.27 \\
130.89 \\
2.39 \\
1.12 \\
-0.51\end{array}$ & 6.3 & 13 Dec $1992 \mathrm{pm}$ \\
\hline 3 & 3.67 & $\begin{array}{l}\text { TSS } \\
\text { ISS } \\
\text { OSS } \\
\text { POC } \\
\text { DOC }\end{array}$ & $\begin{array}{r}242.93 \\
237.01 \\
5.92 \\
1.73 \\
8.83\end{array}$ & $\begin{array}{r}223.23 \\
217.70 \\
5.54 \\
1.59 \\
12.46\end{array}$ & $\begin{array}{r}19.70 \\
19.31 \\
0.39 \\
0.14 \\
-3.63\end{array}$ & 14.1 & 04 May 1993 pm \\
\hline 2.99 & 14.76 & $\begin{array}{l}\text { TSS } \\
\text { ISS } \\
\text { OSS } \\
\text { POC } \\
\text { DOC }\end{array}$ & $\begin{array}{r}55.65 \\
50.43 \\
5.22 \\
1.88 \\
6.83\end{array}$ & $\begin{array}{r}21.20 \\
15.67 \\
5.52 \\
2.68 \\
7.89\end{array}$ & $\begin{array}{l}34.45 \\
34.75 \\
-0.30 \\
-0.80 \\
-1.06\end{array}$ & 15.5 & 19 Jul $1993 \mathrm{am}$ \\
\hline 2.8 & -2.99 & $\begin{array}{l}\text { TSS } \\
\text { ISS } \\
\text { OSS } \\
\text { POC } \\
\text { DOC }\end{array}$ & $\begin{array}{r}81.16 \\
75.98 \\
5.16 \\
2.08 \\
4.79\end{array}$ & $\begin{array}{r}64.82 \\
58.65 \\
6.16 \\
2.47 \\
4.95\end{array}$ & $\begin{array}{l}16.35 \\
17.33 \\
-1.00 \\
-0.39 \\
-0.16\end{array}$ & 4.9 & 10 Dec $1992 \mathrm{pm}$ \\
\hline 2.68 & 26.44 & $\begin{array}{l}\text { TSS } \\
\text { ISS } \\
\text { OSS } \\
\text { POC } \\
\text { DOC }\end{array}$ & $\begin{array}{r}27.40 \\
25.01 \\
2.39 \\
0.18 \\
1.69\end{array}$ & $\begin{array}{r}14.19 \\
13.84 \\
0.35 \\
0.20 \\
1.56\end{array}$ & $\begin{array}{r}13.21 \\
11.17 \\
2.04 \\
-0.02 \\
0.13\end{array}$ & 14.7 & 03 May 1993 pm \\
\hline 2.42 & 11.48 & $\begin{array}{l}\text { TSS } \\
\text { ISS } \\
\text { OSS } \\
\text { POC } \\
\text { DOC }\end{array}$ & $\begin{array}{r}18.82 \\
17.07 \\
1.75 \\
0.62 \\
1.01\end{array}$ & $\begin{array}{r}34.67 \\
29.15 \\
5.52 \\
2.25 \\
5.82\end{array}$ & $\begin{array}{r}-15.84 \\
-12.07 \\
-3.77 \\
-1.63 \\
-4.81\end{array}$ & 13.5 & 13 Sep 1993 pm \\
\hline
\end{tabular}




\section{MODELS AND THEIR RESULTS}

\section{Using mean net exchange of the whole sample population}

Model 1a: Woodroffe (1985) suggests that where a small number of sample tides are being used to characterise annual material exchanges, the simplest method is to multiply the average net material exchange by the number of tides in the year In particulate material flux calculations, however, it is important to consider the overmarsh tide sub-set of the annual total which provides an opportunity for exchange with the vegetated surface (French \& Stoddart 1992). At Salicornia Marsh, approximately $50 \%$ of the tides were overmarsh; the exact figure used in extrapolation was 390 (see Table 2)

$$
M_{\mathrm{A}}=\bar{m}_{\text {net }} \cdot N
$$

where $M_{A}$ is the annual tidal material exchange; $N$ is the number of overmarsh tides in the year, and $m_{\text {net }}$ is the mean net material exchange in the sample population.

Model 1b: An additional calculation was carried out as an alternative way of generating $M_{\mathrm{A}}$ using the mean flood and the mean ebb transports:

$$
M_{\mathrm{A}}=\left(\bar{t}_{\mathrm{F}}-\bar{t}_{\mathrm{E}}\right) \cdot \mathrm{N}
$$

where $\bar{t}_{\mathrm{F}}$ is the mean flood transport in the sample pop- ulation and $\bar{t}_{\mathrm{E}}$ is the mean ebb transport in the sample population.

\section{Using mean net exchange by stage groups in the sample population}

Model 2a. A second means of extrapolation was used by Dankers et al. (1984) in their study of material transports through the Ems-Dollard Estuary. Dankers et al. recognised that the volume of the tidal prism must affect the magnitude of material transport and hence exchange. Maximum tidal stage, a surrogate of tidal prism volume, was used to divide the tidal sample population into groups. Two stage groups were defined for this calculation: lower overmarsh tides (0 to $110 \mathrm{~cm}$ above bankfull; 356 of 390 overmarsh tides) and higher overmarsh tides (>110 $\mathrm{cm}$ above bankfull; 34 tides). At this latter stage the shingle laterals enclosing the marsh (Fig. 1), and the overlying vegetation, are 'drowned out', and transfers of material and water can occur with surrounding marshes.

$$
M_{\mathrm{A}}=\left(\bar{m}_{\mathrm{L}} \cdot \mathrm{N}_{\mathrm{L}}\right)+\left(\bar{m}_{\mathrm{H}} \cdot \mathrm{N}_{\mathrm{H}}\right)
$$

where $\bar{m}_{\mathrm{L}}$ is the mean net material exchange of sampled lower overmarsh tides; $N_{L}$ is the number of lower overmarsh tides in the sample year; $\bar{m}_{H}$ is the mean net material exchange of sampled higher overmarsh tides

Table 2. Summary of the different annual material budgets from Salicornia Marsh using (where possible) 4 different methods. Methods 1, 2 and 3 each have 2 modes of calculation, a and b: a-type calculcitions use the mean net exchange of the sample population, while b-type calculations use the mean flood and ebb transports. Values for methods 1, 2 and 3 include the standard error terms (for error calculation details see Squires 1989). Values for method 4 include the standard error of the estimate (Norcliffe

\begin{tabular}{|c|c|c|c|c|c|}
\hline $\begin{array}{l}\text { Material } \\
\text { class }\end{array}$ & $\begin{array}{c}\text { Type of } \\
\text { calculation }\end{array}$ & $\begin{array}{l}\text { Method } 1 \\
\text { Applying mean } \\
\text { exchanges or transports } \\
\text { from the whole dataset } \\
\text { to the annual population }\end{array}$ & $\begin{array}{l}\text { Method } 2 \\
\text { Applying mean } \\
\text { exchanges or transports } \\
\text { from stage groups within } \\
\text { the sample population to } \\
\text { stage groups within the } \\
\text { annual population }\end{array}$ & $\begin{array}{c}\text { Method } 3 \\
\text { Applying mean } \\
\text { exchanges or transports } \\
\text { from seasonal groups within } \\
\text { the sample population to } \\
\text { seasonal groups within the } \\
\text { annual population }\end{array}$ & $\begin{array}{l}\text { Method } 4 \\
\text { Multiple } \\
\text { regression } \\
\text { technique }\end{array}$ \\
\hline $\mathrm{TSS}_{C}$ (tonnes) & $\begin{array}{l}a \\
b\end{array}$ & $\begin{array}{l}50.7 \pm 53.0 \\
49.2 \pm 93.5\end{array}$ & $\begin{array}{l}41.7 \pm 39.6 \\
41.3 \pm 79.3\end{array}$ & $\begin{array}{l}48.1 \pm 27.2 \\
46.9 \pm 536\end{array}$ & $42.0 \pm 1.4$ \\
\hline $\mathrm{TSS}_{\mathrm{F}}$ (tonnes) & $\begin{array}{l}\mathrm{a} \\
\mathrm{b}\end{array}$ & $\begin{array}{l}32.2 \pm 30.7 \\
34.7 \pm 68.2\end{array}$ & $\begin{array}{l}27.8 \pm 22.3 \\
26.8 \pm 39.5\end{array}$ & $\begin{array}{l}34.3 \pm 9.0 \\
34.3 \pm 26.1\end{array}$ & $27.7 \pm 1.2$ \\
\hline ISS (tonnes) & $\begin{array}{l}a \\
b\end{array}$ & $\begin{array}{l}43.7 \pm 49.3 \\
43.9 \pm 87.1\end{array}$ & $\begin{array}{l}38.5 \pm 40.3 \\
38.6 \pm 74.2\end{array}$ & $\begin{array}{l}45.1 \pm 27.5 \\
45.2 \pm 54.5\end{array}$ & $31.7 \pm 1.3$ \\
\hline $\mathrm{OSS}_{\mathrm{C}}(\mathrm{kg})$ & $\begin{array}{l}a \\
b\end{array}$ & $\begin{aligned} 23.0 & \pm 970 \\
3.0 & \pm 3200\end{aligned}$ & $\begin{array}{l}-13.0 \pm 780 \\
-35.0 \pm 2900\end{array}$ & $\begin{aligned} 22.0 & \pm 710 \\
1.0 & \pm 2100\end{aligned}$ & \\
\hline$P O C_{C}(\mathrm{~kg})$ & $\begin{array}{l}a \\
b\end{array}$ & $\begin{array}{l}-146 \pm 440 \\
-138 \pm 1600\end{array}$ & $\begin{array}{l}-95.1 \pm 345 \\
-92.0 \pm 1330\end{array}$ & $\begin{array}{l}-147 \pm 326 \\
-138 \pm 1130\end{array}$ & \\
\hline $\mathrm{DOC}_{C}(\mathrm{~kg})$ & $\begin{array}{l}a \\
b\end{array}$ & $\begin{array}{l}-162 \pm 1290 \\
-162 \pm 3300\end{array}$ & $\begin{array}{l}-112 \pm 1200 \\
-112 \pm 2800\end{array}$ & $\begin{array}{l}-209 \pm 836 \\
-209 \pm 2480\end{array}$ & \\
\hline
\end{tabular}
1979). Positive estimates are imports; negative estimates are exports. c: based on data collected at the creek station $\mathrm{F}_{\mathrm{F}}$ : based on data collected at the flume station 
and $N_{1 t}$ is the number of higher overmarsh tides in the sample year.

Model 2b: An alternative method of calculating the estimated net exchange from the difference between the estimated flood and ebb transports is also presented:

$$
M_{\mathrm{A}}=\left(\bar{t}_{\mathrm{LF}}-\bar{t}_{\mathrm{LE}}\right) \cdot \mathrm{N}_{\mathrm{L}}+\left(\bar{t}_{\mathrm{HF}}-\bar{t}_{\mathrm{HE}}\right) \cdot \mathrm{N}_{\mathrm{H}}
$$

where $\bar{t}_{\mathrm{LF}}$ is the mean flood material transport of sampled lower overmarsh tides; $\bar{t}_{2, \mathrm{r}}$ is the mean ebb material transport of sampled lower overmarsh tides: $\bar{t}_{\mathrm{HF}}$ is the mean flood material transport of sampled higher overmarsh tides and $\bar{t}_{111}$ is the mean ebb material transport of sampled higher overmarsh tides.

\section{Using mean net exchange of seasonal groups of the sample population}

Model 3a: Settlemyre \& Gardner (1977) used the pronounced seasonality of water temperature observed at Dill Creek, Virginia (USA), as a means of dividing their dataset. At Salicornia Marsh seasonal groups were defined according to recorded water temperature: 'summer' tides occurred in months with mean water temperatures above $10^{\circ} \mathrm{C}$ and 'winter' tides when mean water temperatures fell below this threshold. The annual estimate, $M_{A}$, (Table 2) was calculated as follows (cf. Roman \& Daiber 1989):

$$
M_{\lambda}=\left(\bar{m}_{\mathrm{S}} \cdot \mathrm{N}_{\mathrm{S}}\right)+\left(m_{\mathrm{W}} \cdot \mathrm{N}_{\mathrm{W}}\right)
$$

where $\bar{m}_{5}$ is the mean net material exchange of sampled 'summer' overmarsh tides, $N_{S}$ is the number of 'summer' overmarsh tides in the sample year, $m_{W}$ is the mean net material exchange of sampled 'winter' overmarsh tides, and $N_{w}$ is the number of 'winter' overmarsh tides in the sample year.

\section{Using the mean transports of seasonal groups in the sample population}

Model $3 b$ : The alternative method of calculating a seasonally-adjusted material budget used the difference between the mean flood and ebb transports for each group, rather than the mean net exchange (Table 2)

$$
M_{\mathrm{A}}=\left(\bar{t}_{\mathrm{SF}}-\bar{t}_{\mathrm{SE}}\right) \cdot \mathrm{N}_{\mathrm{S}}+\left(\bar{t}_{\mathrm{WF}}-\bar{t}_{\mathrm{WE}}\right) \cdot \mathrm{N}_{\mathrm{W}}
$$

where $\bar{t}_{\mathrm{SF}}$ is the mean flood material transport of sampled 'summer' overmarsh tides, $\bar{t}_{\mathrm{SE}}$ is the mean ebb material transport of sampled 'summer' overmarsh tides, $\bar{t}_{W F}$ is the mean flood material transport of sampled 'winter' overmarsh tides, and $\bar{t}_{W E}$ is the mean ebb material transport of sampled 'winter' overmarsh tides.

\section{Using a multiple regression relating material exchange to environmental variables}

Model 4: Williams et al. (1992) suggest the most complex method of performing the extrapolation from measured exchanges to annual exchanges using a multiple regression model. A stepwise multiple regression model was applied to the Salicornia Marsh dataset using flow depth (S) and water temperature ( $\left.T_{\mathrm{w}}\right)$ as the independent variables predicting the net import of TSS at the creek station.

This relationship is significant at the $99 \%$ level:

$$
\begin{aligned}
\text { Net TSS (import) }= & 167.697 \mathrm{~S}-17.331 T_{\mathrm{w}}-244.558 \\
& \mathrm{R}^{2}=0.623
\end{aligned}
$$

This model was then used to estimate the annual budget for TSS exchange, measured at the creek station.

$$
M_{\mathrm{A}}=\sum_{i=1}^{\mathrm{N}} \hat{\mathrm{m}}_{i}
$$

where $M_{\mathrm{A}}$ is the total annual tidal material exchange and $\hat{m}_{1}$ is the predicted exchange of TSS for the $i^{\text {th }}$ overmarsh tide in the sample year

\section{DISCUSSION}

The examples for calculating annual material budgets for Salicornia Marsh indicate that one material flux dataset can be used to generate different estimates depending on the assumptions underlying the calculation. The dependence of the estimate on the method implies that published annual material budgets must not be viewed outside the context of the calculation method. In addition, it implies that the comparison of annual budget studies for different marshes must be made with caution if the method of calculation varies between studies.

The reliability of each method can be gauged from the size of the errors it generates. Results from Salicornia Marsh suggest that in most cases the errors are of a magnitude similar to that of the resulting budget. The annual budget estimates for each class of material increase in reliability from Method 1 a to Method 4, as illustrated in Fig. 2 which shows how the error bars decrease as the method of calculation takes increasing account of the factors influencing tidal material exchanges. This is because the assumptions used in the calculations become increasingly more representative of the dataset and the annual overmarsh tidal population. Method 1a assumes that the mean exchange of the dataset is equivalent to the mean exchange of the annual population. This very crude assumption is reflected in the magnitude of the associated error term. Methods $2 \mathrm{a}$ and 3 a make allowances for the tidal char- 


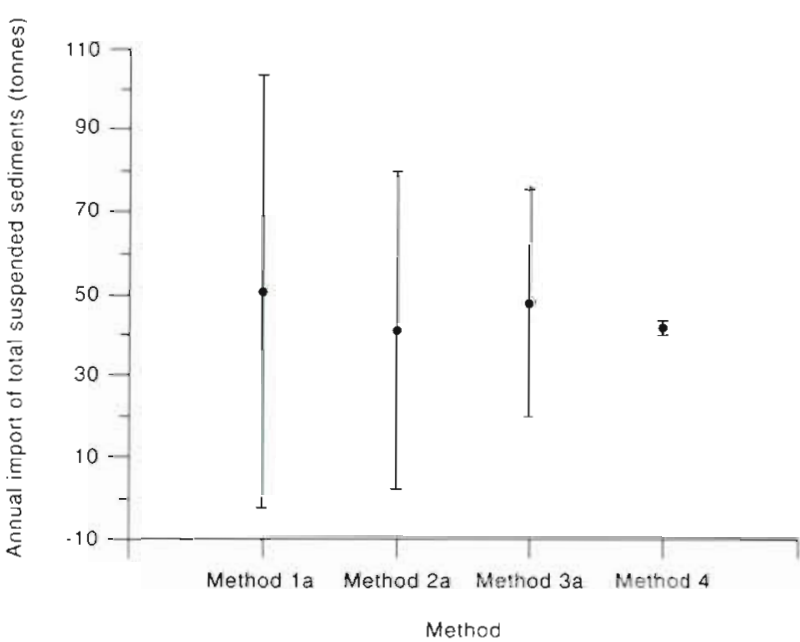

Fig. 2. Estimates of total suspended sediment input to Salicornia Marsh (means and error terms) by method of flux calculation

acteristics which affect material transports, namely stage and water temperature. However there is still an assumption that the mean of part of the dataset can be applied directly to a large proportion of the annual population. Method 4, where it can be applied to material budget calculation, produces the smallest errors. This is because the combined effect of stage and water temperature on the sample population is applied to each tide in the annual population according to its individual stage and temperature characteristics, where the latter is a surrogate of seasonal influences.

Where the difference between the flood and the ebb transports of a class of material is a very small proportion of the transports themselves, the error term associated with the net exchange will be relatively large (McCave 1979, Chambers et al. 1994). The effect of this source of error on the annual budget figure can be gauged by comparing the results of Methods $1 \mathrm{~b}, 2 \mathrm{~b}$ and $3 b$ with those of Methods $1 \mathrm{a}, 2 \mathrm{a}$ and $3 \mathrm{a}$ respectively. The ' $b$ ' methods consistently produce much larger estimates than the 'a' methods. This is because the ' $b$ ' methods include an error associated with the subtraction of ebb material transport from flood material transport, while the 'a' methods make no allowance for this error. Interestingly, most of the studies which attempt to calculate annual material budgets use ' $a$ 'type methods, and thus avoid including the error due to subtraction (e.g. Heinle \& Flemer 1976, Settlemyre \& Gardner 1977, Borey et al. 1983, Dankers et al. 1984, Chalmers et al. 1985, Woodroffe 1985c, Dame et al. 1986, Williams et al. 1992).

Where a number of different methods produce results showing consistency with regard to the direction of net material exchange, the net function of the marsh in relation to that class of material can be estab- lished with a measure of certainty. Salicornia Marsh, for example, is a net importer of both total suspended sediment and inorganic suspended sediment throughout the year. However, where different methods produce different estimates of the direction of net annual exchange, or where the magnitude of the estimate is smaller than the error term regardless of the method used, uncertainty must remain regarding the function of the marsh with respect to that material. The estimates of organic suspended sediment exchange in Salicornia Marsh give conflicting indications of the direction of exchange, and the estimates of both dissolved and particulate organic carbon exchange have error terms in excess of the estimate itself. It would therefore be misleading to state the function of the marsh in relation to these materials at an annual timescale simply on the basis of these calculations.

The dataset collected at Salicornia Marsh did not contain any extreme events, such as storm surges, and hence no conclusion on the effect of these events on the annual material budgets of North Norfolk marshes can be gauged. However, it is important to note that high magnitude, low frequency events have been found to significantly influence the magnitude and even direction of annual material exchange budgets in other systems (Stevenson et al. 1988, Chambers et al. 1994j. Asjes \& Dankers (1994) found that in a Dutch salt marsh, the Shlufter, the export of coarse organic matter during 5 storm tides could amount to $55 \%$ of the annual import budget. The annual net import of inorganic sediment calculated by Settlemyre \& Gardner (1977) was due almost entirely to the import during 2 out of the 25 tides in their sample. The 2 tides were noted to have been preceded by strong wave scour near the mouth of the creek system. Stumpf (1983) did not calculate an annual budget for Holland. Glade Marsh, Delaware (USA), but observed that 'normal' tidal flooding did not produce enough sediment input to maintain marsh elevation while 1 or 2 storm events in a year could introduce enough sediment to the vegetated surface to compensate for the annual rate of local relative sea-level rise

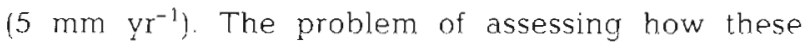
events contribute to marsh function remains unresolved. Stevenson et al. (1988) conclude that storm events can contribute either to material import or export. Indeed the effect of these events may not be a question which can be addressed effectively by computing annual material budgets for 2 reasons: firstly, there is the difficulty of monitoring an event whose occurrence is unpredicted, and secondly, by definition, important extreme events will have a return period much greater than $1 \mathrm{yr}$. The effect of such an event has to be viewed in a temporal context longer than the annual budget. 


\section{CONCLUSION}

This paper shows that even using a single dataset the method of budget calculation chosen has a large effect on the estimate of the annual material exchange. Yet such exchanges have been used to infer marsh function, and the wider role of marshes in estuarine and coastal sediment and nutrient dynamics. The evaluation of marsh function and ecological significance might be improved by adopting 3 protocols. Firstly, reporting of annual budgets should allow for access to, and interrogation of, original datasets. Secondly, where possible, budgetary calculations should be made using a range of methods and approaches. Thus, for example, evaluation of marsh sedimentary status should combine estimates of marsh performance based on tidal exchange studies; sediment trapping experiments; and measurements of marsh surface elevation change. Thirdly, such studies will be better served by experimental designs which aim to characterise the linkages between tidal regime, patterns of marsh surface sedimentation and elevation change and vegetation growth and decay. These interrelationships may be best seen within wetlands over individual tidal cycles where measurements are made with high temporal resolution, but within a framework of a range of locations, at different seasons of the year and, if at all possible, including extreme meteorological and tidal conditions. Understandings gained in this way may be very valuable in informing discussions of marsh function at larger spatial scales and longer timescales.

Acknowledgements. This work was undertaken through a Department of Education for Northern Ireland research studentshup to A.L.M., with additional support from the Philip Lake Fund, University of Cambridge. lccess to the field site was granted by English Nature. Fieldwork assistance was given by N. S. Arnold, J R. French, I. Moeller, D. Thomas, G. O. Williams, S. N. Lane, A. Grigg, J. Jardine, L Copeland, H. Spencer, T Mayo, D. Holtgen, S. Hay, G. Dhillon and V. Popovsk. Organic carbon analyses were carred out in the Oceanography Department, Southampton University, with the permission of P. J. Statham and M. Varney and the help of S. Jones and P. Goody. Sediment analyses were carried out in the Department of Geography. Cambridge University with the cooperation of S. Purkman and W. Hall, J. R. French usefully commented on an edrly draft of this paper. Original datasets are avallable from the corresponding author

\section{LITERATURE CITED}

Allen JRL (1990) Salt-marsh growth and stratification: a numerical model with special reference to the Severn Estuary, southwest Britain. Mar Geol 95:77-96

Asjes J, Dankers N (1994) Variations in tidal processes between a Dutch salt marsh, the Shlufter, and the North Sea. In: Mitsch WJ (ed) Global wetlands: old world and new. Elsevier, Amsterdam, p 210-214

Borey RB, Harcombe PA, Fisher FM (1983) Water and organic carbon fluxes from an irregularly flooded brackish marsh on the upper Texas coast, USA. Estuar Coast Shelf Sci 16: $379-402$

Chalmers AG. Weigert RG, Wolf PL (1985) Carbon balance in a salt marsh: interactions of diffusive export, tidal deposition and rainfall-caused erosion. Estuar Coast Shelf Sci 21: $757-771$

Chambers RM, Smuth SV, Hollubaugh JT (1994) An ecosystem level context for tidal exchange studies in the salt marshes of Tomales Bay, California, USA. In: Mitsch WJ (ed) Global wetlands: old world and new. Elsevier, Amsterdam, p 265-276

Childers DL, McKellar HN, Dame RF, Sklar FH, Blood ER 11993) A dynamic nutrient budget of subsystem interactrons in a salt-marsh estuary. Estuar Coast Shelf Sci 36: $105-131$

Dame RF, Chrzanowskı T, Bildstein K, Kjerfve B, McKellar $H_{1}$ Nelson D, Spurner J, Stancyk S, Stevenson H, Vernberg J, Zingmark R (1986) The outwelling hypothesis and the North Inlet, South Carolina. Mar Ecol Prog Ser 33: $217-229$

Dame RF, Spurrier JD, Williams TM, KJerfve B, Zingmark RG, Wolaver TG, Chrzanowski TH, McKellar HN, Vernberg FJ (1991) Annual material processing by a salt marsh estuarine basin in South Carolina, USA. Mar Ecol Prog Ser 72: $153-166$

Dankers $N$, Binsbergen $M$, Zegers $K$, Laane $R$, Van der Loef $M$ (1984) Transportation of water, particulate and dissolved organic and inorganıc matter between a salt marsh and the Ems-Dollard Estuary. Estuar Coast Shelf Sci 19: $143-165$

French JR, Stoddart DS (1992) Hydrodynamics of saltmarsh creek systems: Implicitions for morphological development and matenal exchange. Earth Surf Proc Landforms: J Br Geomorph Res Group 17:235-252

Heinle DR, Flemer DA (1976) Flows of materials between poorly flooded tidal marshes and an estuary. Mar Biol 35: $359-373$

McCave IN (1979) Suspended sediment. In: Dyer KR (ed) Estuarine bydrography and sedimentation. Cambridge University Press, Cambridge, p 131-185

Murray AL (1995) Tidal exchanges in a back-barrier salt marsh, north Norfolk, England. PhD thesis, University of Cambridge

Norcliffe GB (1977) Inferential statistics for geographers. Hutchinson, London

Odum EP (1968) A research challenge: evaluating the productivity of coastal and estuarine water Proc 2nd Sea Grant Conference. Graduate School of Oceanography. University of Rhode lsland, Newport, p 63-64

Odum EP (1980) The status of three ecosystem-level hypotheses regarding saltmarsh estuaries: tidal subsidy, outwelling and detritus-based food chains. In: Kennedy VS (ed) Estuarine perspectıves. Academic Press, New York, p 485-4.95

Roman CT, Daiber FC (1989) Organic carbon flux through a Delaware Bay salt marsh: tıdal exchange, particle size dıstribution, and storms. Mar Ecol Prog Ser 54:149-156

Settlemyre JL, Gardner LR (1977) Suspended sediment flux through a salt marsh drainage basin. Estuar Coast Mar Sci 5:653-663

Squires GL (1989) Practical physics, 3rd edn. Cambridge University Press, Cambridge

Strahler AN (1964) Quantitative geomorphology of drainage basins and channel networks. In: Chow VT (ed) Handbook of applied hydrology McGraw-Hill, New York, Section $4-$-II, p $39-76$ 
Statham PJ, Williams PJ (1983) Automated chemical analysis In: Grasshof K, Ehrhardt M, Kremling K (eds) Methods of seawater analysis. Verlag Chemie, Weinheim, p 380-395

Stevenson JC, Ward LG, Kearney MS (1988) Sediment transport and trapping in salt marsh systems: implications of tidal flux studies. Mar Geol 80:37-59

Stumpf RP (1983) The process of sedimentation on the surface of a salt marsh. Estuar Coast Shelf Sci 17:495-508

Taylor DI, Allanson BR (1995) Organic carbon fluxes between a high marsh and estuary, and the inapplicability of the outwelling hypothesis. Mar Ecol Prog Ser 120:263-270

This article was submitted to the editor
Williams TM, Wolaver TG, Dame RF, Spurrier JD (1992) The Bly Creek ecosystem study - organic carbon exchange within a euhaline salt marsh basin, North Inlet, South Carolina. J Exp Mar Biol Ecol 163:125-139

Wolaver TG, Whiting G, Dame R, Williams $T$, Spurrier JD (1988) Bly Creek ecosystem study - nitrogen exchange within a euhaline salt marsh basin of North Inlet, South Carolina. Mar Ecol Prog Ser 49:107-116

Woodroffe CD (1985) Studies of a mangrove basin. Tuff Crater, New Zealand: 3 , The flux of organic and inorganic particulate matter. Estuar Coast Shelf Sci 20:447-461

Manuscript first recejved: July 22, 1996

Revised version accepted: February 25, 1997 